\title{
H2AC6 wt Allele
}

National Cancer Institute

\section{Source}

National Cancer Institute. H2AC6 wt Allele. NCI Thesaurus. Code C162893.

Human H2AC6 wild-type allele is located in the vicinity of $6 \mathrm{p} 22.2$ and is approximately 15 $\mathrm{kb}$ in length. This allele, which encodes histone H2A type 1-C protein, is involved in nucleosome formation. 